\title{
Strategies to Retain Millennial Employees at Full-Service Restaurants
}

\author{
Candace A. Ruiz \\ Colorado Community College System \\ Anne Davis \\ Walden University
}

\begin{abstract}
Some supervisors lack effective strategies to retain millennial-generation employees. The purpose of this multicase study was to explore effective strategies to retain culinary-educated millennial employees in a full-service restaurant. Nine millennials and three supervisors from three full-service restaurants in Denver, Colorado, consented to semistructured interviews concerning retention strategies. Herzberg's two-factor theory served to guide the scope and the data analysis for the multicase study. Ten subcategories emerged from the three themes that aligned with Herzberg's motivation factors, hygiene factors, and millennial values and attitudes. The 10 subcategories were developed suggesting effective strategies differ by supervisor. Among the 10 subcategories, the most prominent were (a) growth and advancement, (b) positive working conditions, and (c) quality and influence of the supervisor.
\end{abstract}

Keywords: millennials, employee retention, employee turnover, Herzberg's two-factor theory, hospitality

\section{Introduction}

By 2020, millennials will make up $47 \%$ of the workforce, demanding relevant and meaningful work with high pay and a sense of accomplishment as key job factors (Deal, Altman, \& Rogelberg, 2010; Schullery, 2013). The millennial employees have values and worldviews different from other generations (Deal et al., 2010; Kultalahti \& Viitala, 2015). Further, millennials approach employment and communication using technology and developing relationships (Hershatter \& Epstein, 2010) and want a flat structure of management, freedom in the workplace, and unspecialized work roles (Gialuisi \& Coetzer, 2013).

Within the hospitality industry, employee turnover is a pressing issue (Boella \& Goss-Turner, 2013). Millennials make up $62 \%$ of hospitality workers and $35 \%$ of the U.S. labor force, with turnover costs as high as $\$ 20,000$ per lost employee (Hertzman, Moreo, \& Wiener, 2015). Millennial hospitality employees leave careers because of long hours, negative work-life balance, and poor compensation (Brown, Thomas, \& Bosselman, 2015). High turnover from the millennial-generation employees creates operational instability for restaurant supervisors (Brown et al., 2015). The millennialgeneration employees may leave an organization when the work is not fun or interesting or when they lack a supportive supervisor (Guchait, Cho, \& Meurs, 2015; Milman \& Dickson, 2014).

High turnover among culinary-educated millennial-generation employees reduces the profitability of full-service restaurants. For business owners and managers, the challenge may be some supervisors 
of full-service restaurants lack effective strategies to retain culinary-educated millennial employees. The purpose of the qualitative multicase study was to explore effective strategies of supervisors to retain culinary-educated millennial employees in a full-service restaurant. The specific population included supervisors of full-service restaurants and culinary-educated millennials located in Denver, Colorado. This study was limited both in terms of geographic location as well as type of restaurant. Strategies to retain millennials may differ in fast food restaurants and fine dining establishments. Further, findings may depend on the local employment conditions in other geographic areas.

\section{Conceptual Framework}

We used Herzberg's two-factor theory as the basis for the conceptual framework. The two-factor theory, also known as the Herzberg motivation-hygiene theory, focused on two types of rewardsmotivators and hygiene factors - to explain employee job satisfaction and dissatisfaction (Herzberg, Mausner, \& Snyderman, 1959). Herzberg et al. researched employee motivation and found salary (hygiene factor) did not contribute to employee satisfaction, but low salary related to employee job dissatisfaction. Herzberg et al. proposed enriching and fulfilling work with a possibility of achievement, recognition, responsibility, and growth were the most effective employee motivators. The two-factor theory, as applied to an organizational setting, was appropriate for the study of management strategies for retaining millennials at a business. Herzberg et al. suggested hygiene factors need to be present in a job to obtain a reasonable level of satisfaction and motivation factors contribute to fulfillment in the workplace.

\section{Hygiene Factors}

The two factors of hygiene and motivation are the distinct attributes of Herzberg's theory. Hygiene factors, also known as maintenance factors, related to issues of the organization or environment, and specifics of the job, and were extrinsic (D. B. Smith \& Shields, 2013). An increase in hygiene factors will not motivate an employee but may reduce job dissatisfaction (Mitchell, 2013). Hooi and Leong (2015) posited hygiene factors of competitive wages and benefits did not help to retain workers. Herzberg et al. (1959) emphasized the opposite of job dissatisfaction was not the satisfaction of the job, but rather no job dissatisfaction. Herzberg et al. studied 203 accountants and asked when the individual felt good or bad about a project or the job. When participants discussed occurrences with bad feelings, the issues were external and aligned with hygiene factors (Dasgupta, Suar, \& Singh, 2014). Job dissatisfactions were extrinsic and included items such as company policies, working conditions, security, and status (Dasgupta et al., 2014). Hygiene factors are the quality of supervisor or physical work conditions and when absent can create job dissatisfaction (Dasgupta et al., 2014).

\section{Motivating Factors}

Motivating factors may create job satisfaction and increase the intention to remain in an organization. According to Herzberg et al. (1959, as cited by Dasgupta et al., 2014) in the study of accountants and engineers; intrinsic job satisfactions were advancement or growth, interesting work, recognition, and responsibility. Work not challenging or meaningful reduces employee motivation and job satisfaction (Herzberg et al., 1959; Putra, Cho, \& Liu, 2015). Intrinsic motivation originates from within an individual and includes personal views, religious beliefs, and political factors (Hazra, Sengupta, \& Ghosh, 2014). Forces of motivation include push or pull factors and can energize a worker (Hazra et al., 2014). Motivational factors such as camaraderie, responsibility, and acknowledgment by supervisors can compensate for the lack of hygiene factors (Alverén, Andersson, Eriksson, Sandoff, \& Wikhamn, 2012). McPhail, Patiar, Herington, Creed, and Davidson (2015) 
posited factors of internal locus of control, variety in the job duties, and a potential for advancement in a career contributed to intention to stay in the hospitality industry. Whereas the ability to take an initiative, a variety of job duties, contributing to the organization, and working autonomously were related to intent to stay at the same job (McPhail et al., 2015).

\section{A Review of the Professional and Academic Literature}

\section{Hospitality Employment Environment}

Culinary-educated individuals are hospitality employees and face unique working environments. Hospitality employment includes jobs in the service industry of accommodations, restaurants, bars, travel, and tourism (Sobaih, 2015). Hospitality employees are the backbone and assets for the industry (Hong, Hao, Kumar, Ramendran, \& Kadiresan, 2012; Ladkin \& Buhalis, 2016), and make up about $8 \%$ of all U.S. employment, with two fifths of the employees in hospitality working part time (U.S. Department of Labor, Bureau of Labor Statistics, 2016). Hospitality is a service industry with employees working in high-pressure environments and with high turnover rates (Wang, 2013). Incivility among hospitality employees and from customers can interrupt business operations and sales performance (Torres, Niekerk, \& Orlowski, 2016). Hospitality employees use the body to perform duties of cooking, cleaning, and entertainment and impose physical and psychological demands with irregular hours (McIntosh \& Harris, 2012). Emotional exhaustion of hospitality workers can lead to low job satisfaction and turnover (Rathi \& Lee, 2016).

\section{Millennial Generation}

A generational cohort has shared experiences, similar ages, and lives in a specific period of historical time (Costanza \& Finkelstein, 2015; Lucas, D'Enbeau, \& Heiden, 2016). In the first quarter of 2015, the millennial-generation cohort made up the largest working generation and surpassed Generation $\mathrm{X}$ as the largest portion of the American workforce (Campione, 2015; Fry, 2015). The millennial generation includes people who were born between 1980 and 2000 (Bolton et al., 2013; Cekada, 2012; T. J. Smith \& Nichols, 2015) and makes up about 76 million Americans (Laird, Harvey, \& Lancaster, 2015). The average tenure for millennials at a job in the Unites States is 3.2 years (Laird et al., 2015). The generation has conditional loyalty and may leave a job for better work at another organization (Altinbasak-Farina \& Guleryuz-Turkel, 2015; Gursoy, Chi, \& Karadag, 2013). Millennial-generation employees are the largest working group to enter the U.S. labor force and represent the future talent pool (Lucas et al., 2016).

Millennial-generation employees differ in communication styles, work habits, attitudes, and motivation (T. J. Smith \& Nichols, 2015). Millennials are a diverse cohort with differing expectations and assumptions about work (Fenich, Scott-Halsell, Ogbeide, \& Hashimoto, 2014). The generation is technology savvy, has global and cultural awareness, and is educated (Allison, 2013). Millennialgeneration employees respond well to new experiences including teamwork, global assignments, diverse people, and off-premise assignments for engagement and motivation (Weyland, 2011). Retention and turnover of millennials have become a challenge for managers as the millennial generation becomes the dominant group in the workforce (Johnson \& Ng, 2015). Retaining millennials at jobs leads to cost savings, knowledge consistency, and economic stability (Hancock, Allen, Bosco, McDaniel, \& Pierce, 2013). Millennial employees in the hospitality industry have higher intention to leave than older generations when job conditions do not fit with work preferences (Lu \& Gursoy, 2016). Job dissatisfaction can lead to intention to leave, job comparisons, and job turnover (Lu \& Gursoy, 2016). Millennials may be our next leaders in business, industry, and 
politics. Understanding millennial traits may help our current leaders embrace differences and utilize strengths for employee retention.

\section{Employee Retention}

Employees may remain at an organization for a variety of reasons. Business success is dependent on experience, knowledge, and skills of the employees within the organization (Nieves \& Haller, 2014). Critical to the success of an organization, business leaders need to understand how to retain and motivate workers (Schuler, 2015). Employee turnover creates challenges for businesses and without a strategy a firm may lose skilled workers, profits, and reputation (Bryant \& Allen, 2013; Swarnalatha \& Vasantham, 2014). Examples of tactics to retain employees included compensation and rewards, employee engagement programs, management opportunities, onboarding and socialization, and training and development (Allen \& Bryant, 2012; Aruna \& Anitha, 2015; Ghosh, Satyawadi, Prasad Joshi, \& Shadman, 2013; Sengupta \& Dev, 2013). Aruna and Anitha (2015) posited the attributes of employee retention are engagement with a good working environment, inspiring leadership, positive working relationships, relevant training and development, good remuneration of pay and reward, organizational policies, and management's interest in employee well-being.

\section{Hospitality employee retention}

Innovative and inclusion programs, along with good supervisors, can help with employee retention. Hospitality human resource managers agree retention of employees is the foremost challenge in talent management (Deery \& Jago, 2015). Wang (2013) posited to improve an employee's work quality and personal life, the hospitality employee can participate in training programs for selfmanagement, learning and problem solving, and to enhance management skills. Good management, incentives, and rewards contribute to retention of jobs in the hospitality industry (Vasquez, 2014). Hospitality managers can support fun interactions at work with coworker socialization as an important strategy to promote retention (Becker \& Tews, 2016).

A sense of community among hospitality workers has replaced the traditional norm of neighborhoods, towns, churches, and other places of interactions in everyday life (McCole, 2015; Robinson, Kralj, Solnet, Goh, \& Callan, 2014). When a hospitality employee feels attached to work during personal life events, the individual may decide to remain (Tews, Stafford, \& Michel, 2014). Employees may use a sense of community as a hygiene factor, and contribute to the intention to remain at an organization (McCole, 2015). Karatepe (2014) posited to help employees feel the organization is investing in the worker's career; organizations should use training, rewards, and career opportunities.

The hospitality industry may undertake corporate social responsibility practices to increase employee retention. Social responsible companies led to better retention of workers (Aguinis \& Glavas, 2012). Hospitality organizations benefited from employer-employee corporate social responsibility engagement activity of having fun, feeling pride, development of skills, and team building (Supanti, Butcher, \& Fredline, 2015). A positive relationship exists between a hospitality employee's perception of corporate social responsibility programs and organizational commitment, which reduces turnover intentions (Kim, Song, \& Lee, 2016). Business practices of corporate social responsibility are expectations of millennial workers (Kultalahti \& Viitala, 2015). Hospitality employees may remain at a job when the employer provides a sense of community, support for professional development, and group activities of community engagement. 


\section{Method}

\section{Research Method}

A qualitative methodology provided the best approach for this study because the purpose was to understand the participants' responses to open-ended interview questions on employee retention. Qualitative research is a method to learn from the personal experiences of the participants (Sergeeva \& Andreeva, 2016), where the words of the participants generate the data (Gale, Heath, Cameron, Rashid, \& Redwood, 2013). In management research, a qualitative method is an accepted process to explore at length a specific phenomenon (Thomas \& Magilvy, 2011).

\section{Design}

We selected a multicase study design for the research study. With a case study design, the researcher can explore phenomena and facilitate the study of contemporary real-life events (Yin, 2013). Case study researchers may use multiple sources of data to include interviews, observations, and archival sources such as documents, charts, and websites, or multiple investigators (Barratt, Choi, \& Li, 2011).

\section{Participant Selection}

The population for this study included millennials and supervisors at full-service restaurants in Denver. We used purposeful sampling to select critical cases. Critical case sampling means to select cases for return of the best information and impact for knowledge development of the study (Palinkas et al., 2013). The participants for the study included three culinary-educated millennials and one supervisor at three full-service restaurants in Denver for a total of 12 participants. To be included in the study, the millennial participants must have had full-time status, been culinary educated, and had worked in the company for at least 2 years. The eligibility requirements for supervisors were that they must have been employees of the same organization as the millennials and the supervisor for the millennial participants for at least 1 year. We ensured privacy of the study participants and replaced the restaurants with the following codes: R01, R02, and R03.

\section{Data Collection}

Data collection consisted primarily of face-to-face semistructured interviews. Fusch and Ness (2015) suggested reaching saturation occurs when no new information, coding, or themes emerge or another researcher could duplicate the study. Data saturation was reached with nine participants, but we interviewed all 12 at three full-service restaurants. To enhance the reliability and validity, we included member checking by providing each participant a summary of the interview to verify we understand the intent of the responses. Member checking allows participants an opportunity to verify the accuracy of the interview interpretation (Morse, 2015). Additional supporting documents to include information on business websites, training manuals, and employee handbooks were gathered from the case study sites. The secondary data can help to verify the strategies used by supervisors for retaining millennials at full-service restaurants.

\section{Findings}

We identified businesses through personal knowledge of full-service restaurants in Denver. For all interviews, the supervisors and millennials responded to five questions for the data collection. 
During the interview process, participants contributed experiences, knowledge, and ideas regarding reasons for remaining at their jobs or strategies for millennial employee retention. The semistructured interviews with open-ended interview questions allowed participants the ability to share their experience of retention practices, and helped answer the research question: How are fullservice restaurant supervisors implementing effective strategies to retain culinary-educated millennial-generation employees?

We read the transcripts and developed 55 codes from the data based on the literature review and the conceptual framework. We grouped codes into families aligned with Herzberg's two-factor theory and millennial values and attitudes. We initially used 51 codes developed inductively from the literature review with codes aligned with Herzberg's two-factor theory of rewards (motivators and hygiene factors) to explain employee job satisfaction and dissatisfaction. We used eight codes of values or attitudes of millennials including: (a) universalism (respect of others, social justice, freedom, peace), (b) conformity (trust of others, empathy, respect, sharing), (c) hedonism (pleasure, enjoy life, indulgence), (d) security (family, health, sense of belonging), (e) success (creative, productive, responsible), (f) power (independent, prestige, freewill), (g) self-respect (self-esteem, well-groomed), and (h) spirituality (harmony, positive thinking; Altinbasak-Farina \& Guleryuz-Turkel, 2015).

We used Herzberg's two-factor theory to identify themes for the presentation of findings (Figure 1). We coded participant comments and documents with 155 occurrences of Herzberg's hygiene factors and 81 for motivation factors. Jamieson, Kirk, Wright, and Andrew (2015) confirmed Herzberg's hygiene factors of working conditions and salary a concern for retention of millennials, whereas Bhatia and Purohit (2014) found the hygiene factors of job security and adequate salary of high importance and motivators. 
Herzberg's hygiene factors

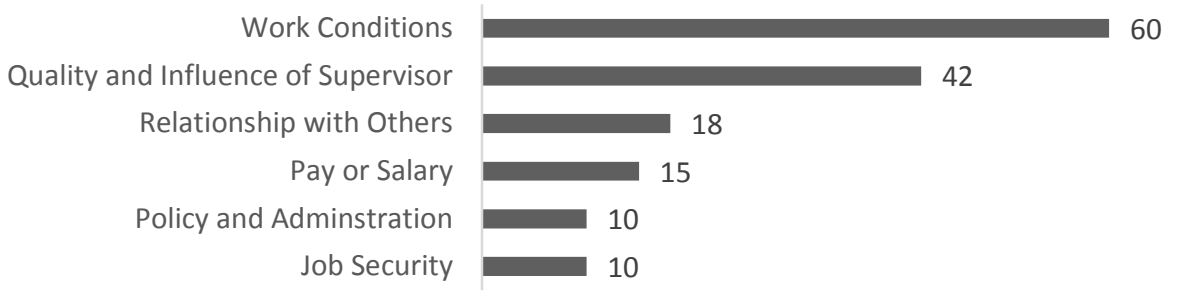

Herzberg's motivation factors

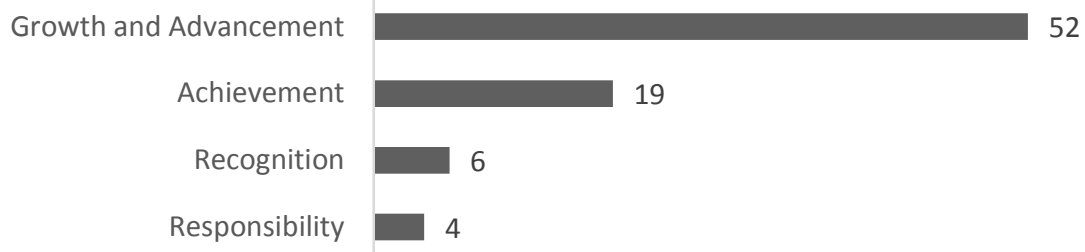

Figure 1. Codes Applied From Participant Interviews and Documents With Alignment to Herzberg's Two-Factor Theory

\section{Theme 1: Hygiene Factors}

Herzberg et al. (1959) determined when hygiene factors were present then these aspects prevented dissatisfaction with a job, were extrinsic, and did not contribute to satisfaction. We used Herzberg's hygiene factors of (a) policy and administration, (b) quality of supervision, (c) pay or salary, (d) relationship with others, (e) work conditions, and (f) job security to identify how full-service restaurant supervisors implemented effective strategies to retain culinary-educated millennialgeneration employees. From the data, we coded 60 instances of working conditions, 42 for quality or influence of the supervisor, 18 for relationships with others, and 15 regarding pay or salary (Figure 2). Herzberg et al. categorized working conditions as a hygiene factor that exists in the workplace and is extrinsic to the worker.

Supervisors can have effective strategies to retain culinary-educated millennial-generation employees with positive working conditions and providing awareness of challenges in the restaurant industry. We coded participant interview responses as working condition when they included instances of employee issues, challenges at work, job engagement and enrichment, or comparison to other jobs.

The restaurant industry work conditions can lead to dissatisfaction. Supervisors may understand to retain millennials the work conditions should not create dissatisfaction but are inherent to the industry. On-the-job injuries and organizational structure were coded as work conditions. 


\section{Herzberg's hygiene factors}

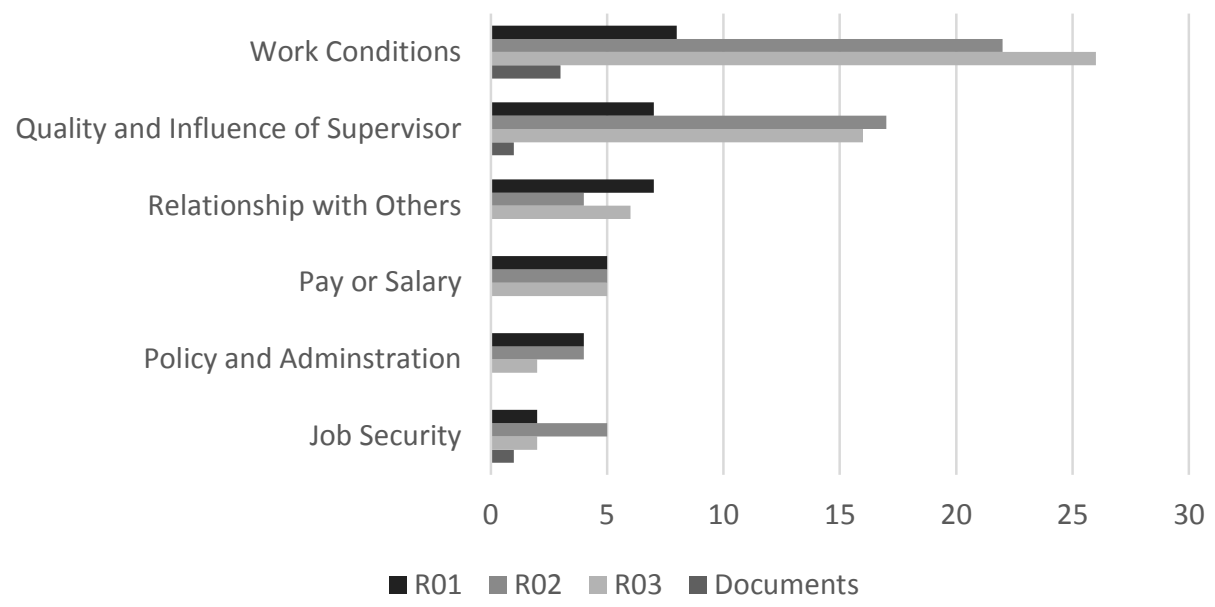

Figure 2. Codes by Restaurant Case Studies Applied From Participant Interviews and Documents With Alignment to Herzberg's Hygiene Factors

Job enrichment activities motivate workers and create positive work conditions (D. B. Smith \& Shields, 2013). Participants noted supervisors can create job enrichment opportunities with catering opportunities and menu creation to create a positive work environment for millennial employees. Our findings aligned with Schullery (2013) who noted millennials require engagement for learning. Supervisors can use the positive working conditions and engagement of the restaurant industry as a retention strategy.

All participants made at least one comment regarding the quality and influence of supervisors. Guchait et al. (2015) found a positive relationship with a supportive supervisor increased an employee's intention to remain at a job. Supervisors from two of the three restaurants emphasized the importance of mentoring for retention of millennial workers. A mentor can help the new employee to understand job expectations (Yang, Wan, \& Fu, 2012). Good supervisors with positive influences created effective strategies to retain culinary-educated millennial-generation employees. Participant feedback supported Dasgupta et al. (2014) and Thomas, Brown, and Thomas (2017) with the confirmation employees leave bosses rather than organizations.

Millennials may remain at a job because of their relationships with others. Seven participants made 18 comments about relationships with others and agreed working with others was a positive experience and a reason to remain at a job. Tense relationships with peers or supervisors create reasons why millennial workers leave an industry or job (Jamieson et al., 2015). Consistent with the findings from the multicase study, supervisors encourage relationships among the employees and throughout the organization (Madden, Mathias, \& Madden, 2015).

The pay or salary may be a positive influence to retain millennial workers but was not mentioned as frequently as other hygiene factors. D. B. Smith and Shields (2013) agreed a paycheck was important 
for workers but relationships with others led to job satisfaction. Our findings aligned for two cases with Haider et al. (2015) that employee compensation has a positive relationship with retention.

\section{Theme 2: Motivation Factors}

Herzberg et al. (1959) identified attributes of job satisfaction as (a) achievement, (b) recognition, (c) responsibility, and (d) growth and advancement. The most frequent code in the data identified as motivators were growth and advancement and achievement. Eight out of the nine millennials stated growth and advancement were reasons they remained at their jobs.

Supervisors use growth and advancement opportunities as a strategy for retention. Yang et al. (2012) suggested opportunities for growth at work increased job satisfaction and commitment to remain at an organization. We coded 52 instances from participants and documents for the theme of growth and advancement (Figure 3). All three supervisors proposed opportunities for advancement were important for millennial retention at the restaurant.

\section{Herzberg's motivation factors}

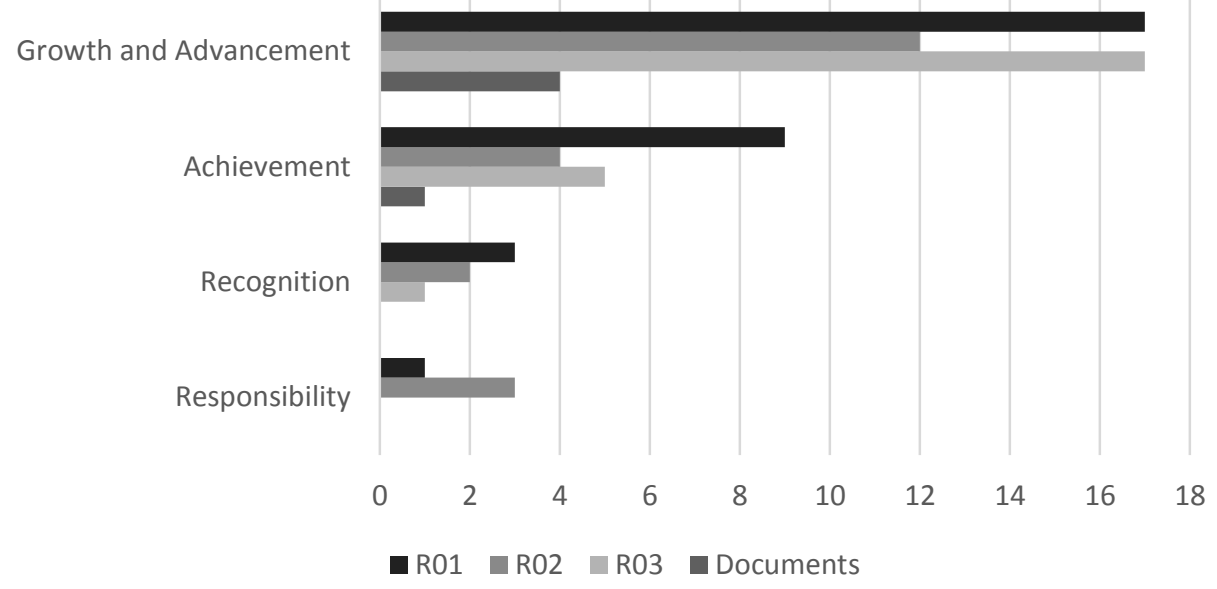

Figure 3. Codes by Restaurant Case Studies Applied From Participant Interviews and Documents With Alignment to Herzberg's Motivation Factors

Supervisors supported growth and advancement with training and development of millennial employees. The data supported Ashar, Ghafoor, Munir, and Hafeez (2013) findings that training and development specific to the organization and position helps to improve skills and abilities of employees. Additionally, employees with unmet expectations of training and development may leave an organization (Yang et al., 2012).

Related documents are part of the data collection process (Yin, 2013). We coded two occurrences of growth and advancement from the company website. The website included hospitality job opportunities, "Great work environment, benefits and opportunity for advancement," (para. 1) and "To ensure proper service from the front line through quality control, training of line cooks and 
ensure proper sanitation levels" (para. 2). We collected the documents to help triangulate the data. The inclusion of advancement and training in the job description can indicate a company culture of employee retention goals.

Herzberg et al. (1959) found workers report good feelings or satisfaction of a job with success and achievement. Restaurant supervisors use strategies of achievement to retain workers. We coded 18 comments from three supervisors and five millennials and one document occurrence for the theme of achievement. Achievement is a motivational factor that reflects team and coworker relationships and leads employees to take on greater responsibility of shared goals and visions (Anitha, 2014). Coded as achievement from the corporate website was the statement, "a results-driven company." Achievement at case study R01 aligned with Yang et al. (2012) when supporting employees with intrinsic motivation such as achievement there is an increase in job satisfaction and commitment to remain at an organization. Our findings aligned with Derby-Davis (2014), who noted the celebration of success and a supportive workplace leads to a sense of achievement.

The restaurant supervisors at the three cases agreed achievement was a motivating factor for retention. At case study R01, millennials felt achievement was a motivator and created job satisfaction. At case study R03, one millennial felt achievement was a day without failure.

\section{Theme 3: Values and Attitude}

Restaurant supervisors with an understanding of values and attitudes of millennials may drive retention strategies for long term employment. From the literature review we coded participant responses and documents of values to explore how full-service restaurant supervisors implemented effective strategies to retain culinary-educated millennial-generation employees. The codes helped us to understand participant attitudes or the way of thinking for millennial employee retention. We coded 68 occurrences of values with the most frequent codes of hedonism (18), security (16), conformity (13), and success (11; Figure 4).

\section{Values and Attitudes}

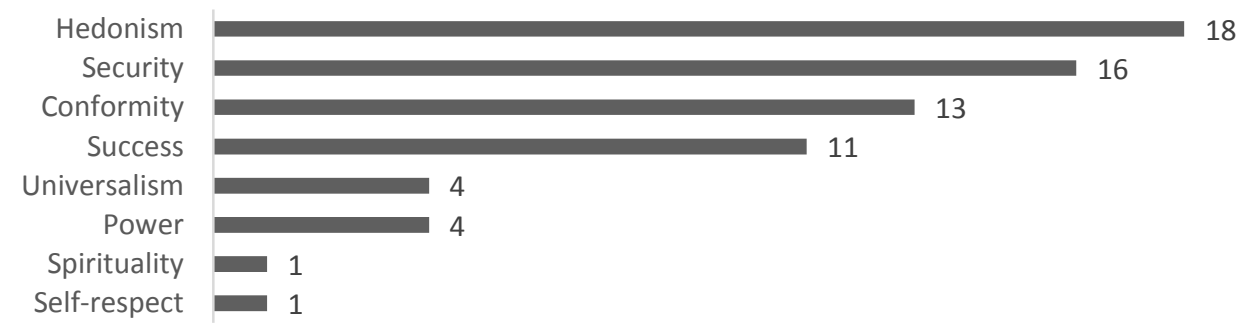

Figure 4. Number of Codes Applied From Participant Interviews and Documents With Alignment to Values and Attitudes

Pleasure, fun, and enjoyment can create positive attitudes for millennial retention. We coded 18 occurrences of hedonism from interviews and documents. To triangulate the millennial value, we coded the corporate website document with hedonism for "We believe it's not just about the work you 
do, but it's about who you are" (para. 2). Our findings aligned with Altinbasak-Farina and GuleryuzTurkel (2015) that millennials value pleasure and fun at work and in life, and as stated by Choi, Kwon, \& Kim (2013) that millennials are more satisfied with jobs if the workplace is fun.

Altinbasak-Farina and Guleryuz-Turkel (2015) suggested security was the influences of family, health, and a sense of belonging. Our findings from case study R01 indicated security a strategy for retention as supported by Campione (2014), who noted that getting to know workers as individuals increased job satisfaction. Our findings from the multicase study indicated the research alignment with Guillot-Soulez and Soulez (2014) that members of the millennial generation are diverse. Security, family, and the sense of belonging were not consistent between case studies.

A value and attitude of millennials is conformity and included trust of others, empathy, respect, and sharing (Altinbasak-Farina \& Guleryuz-Turkel, 2015). The findings for case study R01 supported Dasgupta et al. (2014) that great leaders create connections and meet the emotional needs of workers. The documents we reviewed included instances of conformity, and conformity is a value supported by the company for the line cook positions. Encompassed in the job advertisement were the following criteria: "Genuinely cares about people; is concerned about their work and nonwork problems; is available and ready to help; is sympathetic to the plight of others not as fortunate; demonstrates real empathy with the joys and pain of others." Our finding from the study aligned with Gallicano, Curtin, and Matthews (2012) that millennials want inclusive communication with management.

The millennial value and attitude of success are intrinsic and include dimensions of creativity, productivity, and responsibility (Altinbasak-Farina \& Guleryuz-Turkel, 2015). Employees with the opportunity for creativity feel liberated and less stressed (Bennett, Pitt, \& Price, 2012). We coded 11 occurrences for the value of success with three occurrences from the documents. Our findings aligned with Brown, Bosselman, and Thomas (2016) that employees may perceive new responsibilities similar to a promotion, thereby increasing intention to remain at a job.

Values and attitudes of millennial-generation employees may be important considerations and drive retention strategies for long-term employment. Millennials value hedonism and want pleasure and fun at work and in life. The value of security was sustained by the supervisors, and some millennials appreciated the family culture. Conformity for millennials was an important value and leaders created connections and met emotional needs of workers. Employees appreciated the value of success with the opportunity for creativity.

\section{Effective Strategies for Retention}

Through the course of data collection and analysis, several effective strategies for retaining culinaryeducated millennial-generation employees at full-service restaurant emerged. Our findings included millennials required engagement for learning and supervisors can use the positive working conditions as a retention strategy. Good supervisors can encourage good working relationships among the employees. In some cases, employee compensation has a positive relationship with retention. Supervisor support for growth and advancement was a reminder to millennials of opportunities for promotions and improved intentions to remain. Supervisors at all three case study sites agreed that a sense of achievement increased job satisfaction and was a motivating factor for retention. Opportunities for off-site catering, mentoring, and building relationships with millennial employees were positive retention strategies. 
Effective strategies for retention also include consideration for values and attitudes of millennials. Restaurant supervisors can encourage making the job fun and increase activities to become acquainted with workers as individuals. Increased communication with management can create success for employees by providing new responsibilities and promotions to increase intentions to remain.

\section{Recommendations for Further Research}

Recommendations for future research exist, including supervisor training to support employee retention practices, back-of-the-house strategies for millennial employee retention, and generational differences of employee retention in full-service restaurants. Supervisors from the study did not provide data on all training they received throughout a career to have strategies for retention of millennial employees.

Limitations of the study included all participants being from Denver restaurants, and we could not generalize the results of the study to other cities, states, or nation. The participants were from one corporation with three restaurant locations. A recommendation for further research could include three different corporate restaurants and three different cities or states. One recommendation for further research could be for the researcher to conduct interviews with participants off-site. Researchers might also look at retention strategies at fast food, fast casual, or fine dining establishments.

\section{Conclusions}

The purpose of the qualitative multicase study was to explore effective strategies of supervisors to retain culinary-educated millennial employees in a full-service restaurant. Nine millennialgeneration employees and three supervisors from a single restaurant corporation with three sites participated in semistructured interviews with open-ended interview questions. We assured credibility with member checking to verify accuracy from participants for the interpretation of the data. We reached data saturation with nine participants and when no new information was added from participants. For supporting information and methodological triangulation, we collected data from the company website and job advertisements. The research question that guided the study asked how full-service restaurant supervisors implement effective strategies to retain culinaryeducated millennial-generation employees.

The conceptual framework of Herzberg's two-factor theory helped to guide the scope and data analysis for the study. Three themes with 10 subcategories emerged from the study findings for strategies of retention: (a) hygiene factors (working conditions, quality and influence of supervisor, relationship with others, and pay and salary), (b) motivation factors (growth and advancement, and achievement), and (c) values and attitudes (hedonism, security, conformity, and success). Findings from the multicase study revealed that restaurant supervisors use multiple methods for millennial employee retention. Creating a positive work conditions in a challenging environment was a strategy for retention. Supervisors encouraged positive aspects of the industry, listened and responded, supported workers, and showed empathy and caring. 


\section{References}

Aguinis, H., \& Glavas, A. (2012). What we know and don't know about corporate social responsibility: A review and research agenda. Journal of Management, 38, 932-968. doi:10.1177/0149206311436079

Allen, D., \& Bryant, P. (2012). Managing employee turnover: Dispelling myths and fostering evidencebased retention strategies. New York, NY: Business Expert Press.

Allison, S. (2013). Employment and the millennials. Youth Studies Australia, 32, 81-84.

Altinbasak-Farina, I., \& Guleryuz-Turkel, G. (2015). Identifying the needs of Gen Y by exploring their value systems: A qualitative study. International Journal of Trade, Economics and Finance, 6, 290-296.

Alverén, E., Andersson, T. D., Eriksson, K., Sandoff, M., \& Wikhamn, W. (2012). Seasonal employees' intention to return and do more than expected. Service Industries Journal, 32, 1957-1972. doi:10.1080/02642069.2011.574280

Anitha, J. (2014). Determinants of employee engagement and their impact on employee performance. International Journal of Productivity and Performance Management, 63, 308-323. doi:10.1108/IJPPM-01-2013-0008

Aruna, M., \& Anitha, J. (2015). Employee retention enablers: Generation Y employees. SCMS Journal of Indian Management, 12, 94-103.

Ashar, M., Ghafoor, M. M., Munir, E., \& Hafeez, S. (2013). The impact of perceptions of training on employee commitment and turnover intention: Evidence from Pakistan. International Journal of Human Resource Studies, 3, 74-88. doi:10.5296/ijhrs.v3i1.2924

Barratt, M., Choi, T. Y., \& Li, M. (2011). Qualitative case studies in operations management: Trends, research outcomes, and future research implications. Journal of Operations Management, 29, 329-342. doi:10.1016/j.jom.2010.06.002

Becker, F. W., \& Tews, M. J. (2016). Fun activities at work: Do they matter to hospitality employees? Journal of Human Resources in Hospitality \& Tourism, 15, 279-296. doi:10.1080/15332845.2016.1147938

Bennett, J., Pitt, M., \& Price, S. (2012). Understanding the impact of generational issues in the workplace. Facilities, 30, 278-288. doi:10.1108/02632771211220086

Bhatia, S., \& Purohit, B. (2014). What motivates government doctors in India to perform better in their job? Journal of Health Management, 16, 149-159. doi:10.1177/0972063413518691

Boella, M., \& Goss-Turner, S. (2013). Human resource management in the hospitality industry: A guide to best practice. New York, NY: Routledge.

Bolton, R. N., Parasuraman, A., Hoefnagels, A., Migchels, N., Kabadayi, S., Gruber, T., ... Solnet, D. (2013). Understanding Generation Y and their use of social media: A review and research agenda. Journal of Service Management, 24, 245-267. doi:10.1108/09564231311326987

Brown, E. A., Bosselman, R. H., \& Thomas, N. J. (2016). Are hospitality graduates making too many compromises? What they give up may lead to turnover. Journal of Human Resources in Hospitality \& Tourism, 15, 133-146. doi:10.1080/15332845.2016.1084853

Brown, E. A., Thomas, N. J., \& Bosselman, R. H. (2015). Are they leaving or staying: A qualitative analysis of turnover issues for Generation Y hospitality employees with a hospitality 
education. International Journal of Hospitality Management, 46, 130-137. doi:10.1016/j.ijhm.2015.01.011

Bryant, P. C., \& Allen, D. G. (2013). Compensation, benefits and employee turnover HR strategies for retaining top talent. Compensation \& Benefits Review, 45, 171-175. doi:10.1177/0886368713494342

Campione, W. A. (2014). The influence of supervisor race, gender, age, and cohort on millennials' job satisfaction. Journal of Business Diversity, 14, 18-34.

Campione, W. A. (2015). Corporate offerings: Why aren't millennials staying? The Journal of Applied Business and Economics, 17, 60-75.

Cekada, T. L. (2012). Training a multigenerational workforce: Understanding key needs and learning styles. Professional Safety, 57, 40-44.

Choi, Y. G., Kwon, J., \& Kim, W. (2013). Effects of attitudes vs experience of workplace fun on employee behaviors. International Journal of Contemporary Hospitality Management, 25, 410-427. doi:10.1108/09596111311311044

Costanza, D. P., \& Finkelstein, L. M. (2015). Generationally based differences in the workplace: Is there a there there? Industrial and Organizational Psychology, 8, 308-323. doi:10.1017/iop.2015.15

Dasgupta, S. A., Suar, D., \& Singh, S. (2014). Managerial communication practices and employees' attitudes and behaviours: A qualitative study. Corporate Communications: An International Journal, 19, 287-302. doi:10.1108/CCIJ-04-2013-0023

Deal, J. J., Altman, D. G., \& Rogelberg, S. G. (2010). Millennials at work: What we know and what we need to do (if anything). Journal of Business and Psychology, 25, 191-199. doi:10.1007/s10869-010-9177-2

Deery, M., \& Jago, L. (2015). Revisiting talent management, work-life balance and retention strategies. International Journal of Contemporary Hospitality Management, 27, 453-472. doi:10.1108/IJCHM-12-2013-0538

Derby-Davis, M. J. (2014). Predictors of nursing faculty's job satisfaction and intent to stay in academe. Journal of Professional Nursing, 30, 19-25. doi:10.1016/j.profnurs.2013.04.001

Fenich, G. G., Scott-Halsell, S., Ogbeide, G.-C., \& Hashimoto, K. (2014). What the millennial generation from around the world prefers in their meetings, conventions, and events. Journal of Convention \& Event Tourism, 15, 236-241. doi:10.1080/15470148.2014.929993

Fry, R. (2015). Millennials surpass Gen Xers as the largest generation in U.S. labor force. Retrieved from http://www.pewresearch.org/fact-tank/2015/05/11/millennials-surpass-gen-xers-as-thelargest-generation-in-u-s-labor-force/

Fusch, P. I., \& Ness, L. R. (2015). Are we there yet? Data saturation in qualitative research. The Qualitative Report, 20, 1408-1416.

Gale, N. K., Heath, G., Cameron, E., Rashid, S., \& Redwood, S. (2013). Using the framework method for the analysis of qualitative data in multi-disciplinary health research. BMC Medical Research Methodology, 13, 1-12. doi:10.1186/1471-2288-13-117

Gallicano, T. D., Curtin, P., \& Matthews, K. (2012). I love what I do, but... a relationship management survey of millennial generation public relations agency employees. Journal of Public Relations Research, 24, 222-242. doi:10.1080/1062726X.2012.671986 
Ghosh, P., Satyawadi, R., Prasad Joshi, J., \& Shadman, M. (2013). Who stays with you? Factors predicting employees' intention to stay. International Journal of Organizational Analysis, 21, 288-312. doi:10.1108/IJOA-Sep-2011-0511

Gialuisi, O., \& Coetzer, A. (2013). An exploratory investigation into voluntary employee turnover and retention in small businesses. Small Enterprise Research, 20, 55-68.

doi:10.5172/ser.2013.20.1.55

Guchait, P., Cho, S., \& Meurs, J. A. (2015). Psychological contracts, perceived organizational and supervisor support: Investigating the impact on intent to leave among hospitality employees in India. Journal of Human Resources in Hospitality \& Tourism, 14, 290-315. doi:10.1080/15332845.2015.1002070

Guillot-Soulez, C., \& Soulez, S. (2014). On the heterogeneity of Generation Y job preferences. Employee Relations, 36, 319-332. doi:10.1108/ER-07-2013-0073

Gursoy, D., Chi, C. G.-Q., \& Karadag, E. (2013). Generational differences in work values and attitudes among frontline and service contact employees. International Journal of Hospitality Management, 32, 40-48. doi:10.1016/j.ijhm.2012.04.002

Haider, M., Rasli, A., Akhtar, C. S., Yusoff, R. B. M., Malik, O. M., Aamir, A., ... Tariq, F. (2015). The impact of human resource practices on employee retention in the telecom sector. International Journal of Economics and Financial Issues, 5, 63-69.

Hancock, J. I., Allen, D. G., Bosco, F. A., McDaniel, K. R., \& Pierce, C. A. (2013). Meta-analytic review of employee turnover as a predictor of firm performance. Journal of Management, 39, 573-603. doi:10.1177/0149206311424943

Hazra, K., Sengupta, P. P., \& Ghosh, P. (2014). Role of motivation on employee's performance in different segments of catering sectors under hospitality industry: An empirical study. Presented at the 2nd International Conference on Business and Information Management (ICBIM), Durgapur, India. doi:10.1109/ICBIM.2014.6970968

Hershatter, A., \& Epstein, M. (2010). Millennials and the world of work: An organization and management perspective. Journal of Business \& Psychology, 25, 211-223. doi:10.1007/s10869-010-9160-y

Hertzman, J. L., Moreo, A. P., \& Wiener, P. J. (2015). Career planning strategies and skills of hospitality management students. Journal of Human Resources in Hospitality \& Tourism, 14, 423-443. doi:10.1080/15332845.2015.1002071

Herzberg, F., Mausner, B., \& Snyderman, B. (1959). The motivation to work. New York, NY: Wiley.

Hong, E. N. C., Hao, L. Z., Kumar, R., Ramendran, C., \& Kadiresan, V. (2012). The effectiveness of human resource management practices. International Journal of Business Research and Management, 3, 60-79.

Hooi, L. W., \& Leong, P. Y. (2015). The impact of employee satisfaction on employee intention to leave: A case study analysis. Journal for International Business and Entrepreneurship Development, 8, 281-299. doi:10.1504/JIBED.2015.070805

Jamieson, I., Kirk, R., Wright, S., \& Andrew, C. (2015). Generation Y New Zealand registered nurses' views about nursing work: A survey of motivation and maintenance factors. Nursing Open, 2, 49-61. doi:10.1002/nop2.16 
Johnson, J. M., \& Ng, E. S. (2015). Money talks or millennials walk the effect of compensation on nonprofit millennial workers sector-switching intentions. Review of Public Personnel Administration, 35, 2-23. doi:10.1177/0734371X15587980

Karatepe, O. M. (2014). The importance of supervisor support for effective hotel employees an empirical investigation in Cameroon. Cornell Hospitality Quarterly, 55, 388-397. doi:10.1177/1938965513511147

Kim, J., Song, H. J., \& Lee, C.-K. (2016). Effects of corporate social responsibility and internal marketing on organizational commitment and turnover intentions. International Journal of Hospitality Management, 55, 25-32. doi:10.1016/j.ijhm.2016.02.007

Kultalahti, S., \& Viitala, R. (2015). Generation Y: Challenging clients for HRM? Journal of Managerial Psychology, 30, 101-114. doi:10.1108/JMP-08-2014-0230

Ladkin, A., \& Buhalis, D. (2016). Online and social media recruitment: Hospitality employer and prospective employee considerations. International Journal of Contemporary Hospitality Management, 28, 327-345. doi:10.1108/IJCHM-05-2014-0218

Laird, M. D., Harvey, P., \& Lancaster, J. (2015). Accountability, entitlement, tenure, and satisfaction in Generation Y. Journal of Managerial Psychology, 30, 87-100. doi:10.1108/JMP-08-20140227

Lu, A. C. C., \& Gursoy, D. (2016). Impact of job burnout on satisfaction and turnover intention: Do generational differences matter? Journal of Hospitality \& Tourism Research, 40, 210-235. doi:10.1177/1096348013495696

Lucas, K., D’Enbeau, S., \& Heiden, E. P. (2016). Generational growing pains as resistance to feminine gendering of organization? An archival analysis of human resource management discourses. Journal of Management Inquiry, 25, 322-337. doi:10.1177/1056492615616692

Madden, L., Mathias, B. D., \& Madden, T. M. (2015). In good company: The impact of perceived organizational support and positive relationships at work on turnover intentions. Management Research Review, 38, 242-263. doi:10.1108/MRR-09-2013-0228

McCole, D. (2015). Seasonal employees the link between sense of community and retention. Journal of Travel Research, 54, 193-205. doi:10.1177/0047287513513169

McIntosh, A., \& Harris, C. (2012). Critical hospitality and work: (In)hospitable employment in the hospitality industry. Hospitality \& Society, 2, 129-135. doi:10.1386/hosp.2.2.129_2

McPhail, R., Patiar, A., Herington, C., Creed, P., \& Davidson, M. (2015). Development and initial validation of a hospitality employees' job satisfaction index: Evidence from Australia. International Journal of Contemporary Hospitality Management, 27, 1814-1838. doi:10.1108/IJCHM-03-2014-0132

Milman, A., \& Dickson, D. (2014). Employment characteristics and retention predictors among hourly employees in large US theme parks and attractions. International Journal of Contemporary Hospitality Management, 26, 447-469. doi:10.1108/IJCHM-04-2013-0178

Mitchell, G. (2013). Selecting the best theory to implement planned change. Nursing Management, 20, 32-37. doi:10.7748/nm2013.04.20.1.32.e1013

Morse, J. M. (2015). Critical analysis of strategies for determining rigor in qualitative inquiry. Qualitative Health Research, 25, 1212-1222. doi:10.1177/1049732315588501 
Nieves, J., \& Haller, S. (2014). Building dynamic capabilities through knowledge resources. Tourism Management, 40, 224-232. doi:10.1016/j.tourman.2013.06.010

Palinkas, L. A., Horwitz, S. M., Green, C. A., Wisdom, J. P., Duan, N., \& Hoagwood, K. (2013). Purposeful sampling for qualitative data collection and analysis in mixed method implementation research. Administration and Policy in Mental Health and Mental Health Services Research, 42, 533-544. doi:10.1007/s10488-013-0528-y

Putra, E. D., Cho, S., \& Liu, J. (2015). Extrinsic and intrinsic motivation on work engagement in the hospitality industry: Test of motivation crowding theory. Tourism and Hospitality Research, 15, 1-14. doi:10.1177/1467358415613393

Rathi, N., \& Lee, K. (2016). Emotional exhaustion and work attitudes: Moderating effect of personality among frontline hospitality employees. Journal of Human Resources in Hospitality \& Tourism, 15, 231-251. doi:10.1080/15332845.2016.1147935

Robinson, R. N. S., Kralj, A., Solnet, D. J., Goh, E., \& Callan, V. (2014). Thinking job embeddedness not turnover: Towards a better understanding of frontline hotel worker retention. International Journal of Hospitality Management, 36, 101-109. doi:10.1016/j.ijhm.2013.08.008

Schuler, R. S. (2015). The 5-C framework for managing talent. Organizational Dynamics, 44, 47-56. doi:10.1016/j.orgdyn.2014.11.006

Schullery, N. M. (2013). Workplace engagement and generational differences in values. Business Communication Quarterly, 76, 252-265. doi:10.1177/1080569913476543

Sengupta, S., \& Dev, S. (2013). What makes employees stay? Strategic Outsourcing: An International Journal, 6, 258-276. doi:10.1108/SO-05-2013-0007

Sergeeva, A., \& Andreeva, T. (2016). Knowledge sharing research: Bringing context back in. Journal of Management Inquiry, 25, 240-261. doi:10.1177/1056492615618271

Smith, D. B., \& Shields, J. (2013). Factors related to social service workers' job satisfaction: Revisiting Herzberg's motivation to work. Administration in Social Work, 37, 189-198. doi:10.1080/03643107.2012.673217

Smith, T. J., \& Nichols, T. (2015). Understanding the millennial generation. Journal of Business Diversity, 15, 39-47.

Sobaih, A. E. E. (2015). Hospitality employment issues in developing countries: The case of Egypt. Journal of Human Resources in Hospitality \& Tourism, 14, 221-243. doi:10.1080/15332845.2014.904167

Supanti, D., Butcher, K., \& Fredline, L. (2015). Enhancing the employer-employee relationship through corporate social responsibility (CSR) engagement. International Journal of Contemporary Hospitality Management, 27, 1479-1498. doi:10.1108/IJCHM-07-2014-0319

Swarnalatha, C., \& Vasantham, S. T. (2014). Employee retention strategies. Golden Research Thoughts, 3, 1-3.

Tews, M. J., Stafford, K., \& Michel, J. W. (2014). Life happens and people matter: Critical events, constituent attachment, and turnover among part-time hospitality employees. International Journal of Hospitality Management, 38, 99-105. doi:10.1016/j.ijhm.2014.01.005 
Thomas, E., \& Magilvy, J. K. (2011). Qualitative rigor or research validity in qualitative research. Journal for Specialists in Pediatric Nursing, 16, 151-155. doi:10.1111/j.17446155.2011.00283.x

Thomas, N. J., Brown, E., \& Thomas, L. Y. (2017). Employee satisfaction and turnover intention: A comparative analysis between front-of-house and back-of-house employees in casinoentertainment venues. Journal of Human Resources in Hospitality \& Tourism, 16, 71-87. doi:10.1080/15332845.2016.1202065

Torres, E. N., Niekerk, M. V., \& Orlowski, M. (2016). Customer and employee incivility and its causal effects in the hospitality industry. Journal of Hospitality Marketing \& Management, Advance online publication. doi:10.1080/19368623.2016.1178620

U.S. Department of Labor, Bureau of Labor Statistics. (2016). Industries at a glance. Retrieved from http://www.bls.gov/iag/tgs/iag70.htm\#iag70emp1.f.P

Vasquez, D. (2014). Employee retention for economic stabilization. International Journal of Management, Economics and Social Sciences, 3, 1-17.

Wang, Y.-F. (2013). Constructing career competency model of hospitality industry employees for career success. International Journal of Contemporary Hospitality Management, 25, 9941016. doi:10.1108/IJCHM-07-2012-0106

Weyland, A. (2011). Engagement and talent management of Gen Y. Industrial and Commercial Training, 43, 439-445. doi:10.1108/00197851111171863

Yang, J.-T., Wan, C.-S., \& Fu, Y.-J. (2012). Qualitative examination of employee turnover and retention strategies in international tourist hotels in Taiwan. International Journal of Hospitality Management, 31, 837-848. doi:10.1016/j.ijhm.2011.10.001

Yin, R. K. (2013). Case study research: Design and methods (5th ed.). Los Angeles, CA: Sage Publications.

The International Journal of Applied Management and Technology (IJAMT), sponsored by Walden University's School of Management, is a peer-reviewed, online journal that addresses contemporary national and international issues related to management and technology. The objectives of the IJAMT are to: (a) encourage collaborative and multi-disciplinary examinations of important issues in business and technology management, and (B) engage scholars and scholar-practitioners in a dynamic and important dialogue.

Walden University Publishing: http://www.publishing.waldenu.edu 